\title{
Deteksi Residu Antibiotik Oksitetrasiklin pada Susu Kambing Peranakan Etawah di Kelurahan Kalipuro, Banyuwangi dengan Uji Bioassay
}

\section{Detection of Oxytetracycline Antibiotic Residues on Etawah Crossbreed Goat in Kalipuro Village, Banyuwangi with Bioassay Test}

\author{
Ratna Ajeng Prameswari ${ }^{1 *}$, Suryanie Sarudji ${ }^{2}$, Ratih Novita Praja ${ }^{2}$, Wiwiek \\ Tyasningsih ${ }^{2}$, Maya Nurwartanti Yunita ${ }^{3}$, Aditya Yudhana ${ }^{4}$ \\ ${ }^{1}$ Bachelor of Veterinary Medicine, ${ }^{2}$ Department of Veterinary Microbiology, ${ }^{3}$ Department of Veterinary \\ Pathology, ${ }^{4}$ Department of Veterinary Parasitology, \\ Faculty of Veterinary Medicine, Universitas Airlangga, \\ UNAIR C- Campus Mulyorejo, Surabaya, East Java, Indonesia 60115 \\ Telp. (031)5993016, Fax. (031)5993015 \\ *Corresponding author: deepra.ajeng@gmail.com
}

\begin{abstract}
Abstrak
Oksitetrasiklin diketahui sebagai salah satu antibiotik yang sering digunakan dalam menangani kasus mastitis pada hewan ternak. Penelitian ini merupakan penelitian deskriptif untuk mengetahui ada atau tidaknya residu oksitetrasiklin pada susu kambing Peranakan Etawah (PE) di Kelurahan Kalipuro, Banyuwangi. Sampel susu di koleksi kemudian dilakukan pengujian residu antibiotik dengan metode uji bioassay menggunakan bakteri standar Bacillus cereus ATCC 11778. Penelitian yang dilakukan pada 26 sampel susu yang di ambil secara acak berasal dari ternak kambing perah PE di dapatkan hasil yang negatif. Hal ini di tunjukkan dengan tidak terbentuknya zona hambat di sekitar well yang diisi sampel susu. Berbeda dengan kontrol postif oksitetrasiklin dengan konsentrasi $1 \mu \mathrm{g} / \mathrm{ml}$ yang menghasilkan zona hambatan sekitar $18 \mathrm{~mm}$. Dapat disimpulkan bahwa 100\% dari 26 jumlah sampel susu kambing PE yang di ambil secara acak dan di periksa dari Kelurahan Kalipuro, Banyuwangi tidak mengandung residu antibiotik oksitetrasiklin.
\end{abstract}

Kata kunci: oksitetrasiklin, Peranakan Etawah, residu antibiotik, susu kambing, uji bioassay

\begin{abstract}
Oxytetracycline are known as one of the antibiotics that are often used in handling mastitis cases in livestock. This study was a descriptive study to determine the presence or absence of oxytetracycline residues in the milk of Etawah crossbreed (PE) goats in Kalipuro Village, Banyuwangi. The milk samples in the collection were then tested for antibiotic residues using the bioassay screening method using the standard bacterium Bacillus cereus ATCC 11778. Research conducted on 26 milk samples taken randomly from PE were obtained negative results. This is indicated by the absence of inhibition zones around the well filled with milk samples. In contrast to positive oxytetracycline control with a concentration of $1 \mu \mathrm{g} / \mathrm{ml}$ which produces a zone of resistance of about $18 \mathrm{~mm}$. It can be concluded that the samples of PE goat milk taken randomly in Kalipuro village, Banyuwangi were not contain antibiotic residues, especially oxytetracycline antibiotics.
\end{abstract}

Key words: antibiotic residue, bioassay test, Etawah crossbreed, goat's milk, oxytetracycline

Received: 19 April 2019

Revised: 29 Mei 2019

Accepted: 14 Juli 2019

\section{PENDAHULUAN}

Residu antibiotika merupakan senyawa asal dan atau metabolitnya yang terdapat dalam jaringan produk hewani dan termasuk juga hasil uraian lainnya dari suatu antibiotika. Residu antibiotika berbahaya apabila ditinjau dari sisi kesehatan manusia, selain itu juga memberikan dampak terhadap beberapa produk hasil olahan susu tertentu. Bahaya potensial residu antibiotika yang terkandung dalam pangan asal hewan secara umum dapat ditinjau dari tiga aspek, yaitu 
aspek toksikologis, aspek mikrobiologis, dan aspek imunopatologis. Residu antibiotik ditinjau dari sisi teknologi pengolahan produk hewan terutama susu, yaitu adanya residu antibiotika dapat menghambat proses fermentasi yang menggunakan mikroba dalam pengolahannya (Ningrum, 2011). Batas maksimum residu yang telah ditetapkan oleh SNI (2000) tentang batas cemaran dan residu antibiotika pada susu yaitu $0.05 \mathrm{mg} / \mathrm{kg}$.

Residu antibiotika termasuk salah satu bahaya kimia yang menjadi permasalahan dalam mewujudkan produk hewan yang berkualitas tinggi. Produk hewan yang baik akan memiliki nilai jual atau ekonomi yang lebih tinggi dan mampu bersaing dalam dunia perdagangan secara luas. Produk hewan termasuk susu saat ini merupakan bahan makanan bergizi tinggi yang dikonsumsi tidak lagi terbatas pada jumlah atau kuantitas, tetapi juga lebih mempertimbangkan aspek mutu atau kualitasnya (Dewi dkk, 2014). Aspek kesehatan hewan dalam pemanfaatan sumber daya ternak lokal juga menjadi tidak kalah penting mengingat penyakit pada hewan dapat ditularkan ke manusia melalui konsumsi susu dan tingkat konsumsi masyarakat terhadap susu semakin tinggi (Suwito dkk., 2014).

Susu dapat mengandung residu antibiotik diperkirakan sebagai akibat pengobatan pada hewan yang mengalami penyakit mastitis. Hal ini disebabkan karena prevalensi kasus mastitis masih sangat tinggi di Indonesia. Mastitis disebabkan oleh beberapa kuman yang terkait dengan sanitasi kandang maupun kondisi ternak yang kurang baik (Bahri dkk, 2005). Adanya residu antibiotika ini dapat meningkatkan bahaya resistensi bakteri, yang dapat terjadi pada intestinal manusia dalam jangka waktu tertentu. Ketidakseimbangan mikrobiota yang terjadi, dapat mengarah pada terjadinya proliferasi dari bakteri berbahaya dan patogen oportunistik. Kejadian yang lebih buruk yaitu apabila bakteri dalam usus telah resisten, kemudian berkembang biak dengna jumlah yang cukup banyak, maka penyakit-penyakit yang disebabkan karena bakteri tersebut akan dapat menyebabkan kematian karena tidak dapat diobati (Ben, 2018).

\section{METODE PENELITIAN}

Metode pada penelitian ini adalah uji bioassay yang bersifat deskriptif. Sampel pada penelitian ini adalah susu kambing Peranakan Etawah (PE) yang berasal dari Kelurahan Kalipuro, Kecamatan Kalipuro, Banyuwangi sejumlah 26 sampel. Sampel kemudian dibawa untuk dilakukan uji lebih lanjut di Laboratorium Instrument PSDKU Universitas Airlangga di Banyuwangi.

Pelaksanaan pengujian dilakukan dalam beberapa tahapan sebagai berikut: dimulai dengan mempersiapkan alat dan bahan yang telah dilakukan proses sterilisasi menggunakan metode sterilisasi basah (autoklaf) maupun sterilisasi kering (oven). Selain alat dan bahan perlu juga disiapkan kultur bakteri Bacillus cereus ATCC 11778 sebagai bakteri standar pengujian residu antibiotik secara Bioassay (SNI, 2000). Pada penelitian ini bakteri yang digunakan berasal dari Balai Besar Laboratorium Kesehatan Surabaya. Bakteri tersebut telah dibuat suspensi dengan konsentrasi standar bakteri untuk pengujian yaitu antara $10^{5}-10^{8}$ sel. Tahap selanjutnya yaitu membuat media MHA berisi kultur bakteri pada cawan Petri dengan metode tuang. Setelah itu dibuatlah well atau sumuran pada cawan media. Kemudian setiap well diisi dengan larutan sampel sebanyak $100 \mu \mathrm{l}$ dengan menggunakan mikropipet. Lalu menempatkan masing - masing cawan Petri pada bidang datar dalam temperatur ruang selama satu jam. Setiap sampel minimal dilakukan pengulangan sebanyak tiga kali (triplo). Kemudian diinkubasikan dalam inkubator bersuhu $30^{\circ} \mathrm{C}$ selama 16 jam sampai 18 jam (Pikeemat, 2009).

Keberadaan residu antibiotika diketahui dengan cara mengamati sampel uji setelah diinkubasikan selama 18 jam. Pengamatan berfokus pada ada atau tidaknya zona hambat pertumbuhan bakteri Bacillus cereus ATCC 11778 di sekitar well yang berisi sampel susu yang menandakan adanya residu antibiotik yang terkandung pada sampel susu.

Data yang diperoleh dari penelitian bersifat kualitatif. Hasil yang didapat disajikan dalam 
bentuk tabel. Kemudian dihitung persentase keberadaan residu antibiotik oksitetrasiklin dari semua sampel yang diuji.

\section{HASIL DAN PEMBAHASAN}

Berdasarkan hasil penelitian yang didapatkan yaitu $100 \%$ dari 26 sampel susu kambing PE di kelurahan Kalipuro, Kecamatan Kalipuro, Banyuwangi menunjukkan hasil negatif residu antibiotik oksitetrasiklin. Hal ini didapatkan berdasarkan pengamatan, yaitu tidak adanya zona hambat pertumbuhan bakteri Bacillus cereus ATCC 11778 sebagai bakteri standar pengujian residu antibiotik oksitetrasiklin pada sekeliling well yang berisi sampel susu. Hasil negatif juga didapatkan pada penelitian terdahulu mengenai residu antibiotik pada susu di beberapa kecamatan di Kabupaten Bogor (Detha, 2017).

Perbedaan yang sangat jelas terlihat antara sampel yang tidak terbentuk zona hambat, dengan kontrol positif oksitetrasiklin $(1 \mu \mathrm{g} / \mathrm{ml})$. Zona hambatan yang dibentuk oleh kontrol positif dari penelitian ini yaitu memiliki diameter sebesar $\pm 18 \mathrm{~mm}$.

Tabel 1 memuat data hasil pengamatan zona hambat yang terbentuk dari 26 sampel yang di ambil oleh peneliti. Dari data di atas dapat di ketahui bahwa semua sampel menunjukkan hasil yang negatif. Untuk kontrol postitif yang menggunakan antibiotik oksitetrasiklin dengan konsentrasi $1 \mu \mathrm{g} / \mathrm{ml}$ menunjukkan zona hambatan sebesar $18 \mathrm{~mm}$ (Gambar 1).

Residu antibiotik pada produk pangan asal hewan merupakan permasalahan yang tidak hanya terjadi di Indonesia tetapi juga terjadi hampir di semua negara. Beberapa peneliti mengemukakan banyaknya penemuan residu antibiotik yang terdapat dalam bahan pangan, khususnya pangan asal hewan. Banyak faktor yang menyebabkan terjadinya residu antibiotika dalam bahan pangan asal hewan. Antibiotik merupakan obat yang sering digunakan dalam bidang peternakan, termasuk hewan ternak penghasil susu. Residu antimikroba saat ini merupakan zat penghambat yang paling sering ditemukan dalam susu, memiliki efek yang tidak diinginkan pada kualitas susu, teknologi pengolahan susu, kualitas produk olahan susu dan permasalahan kesehatan bagi manusia (Panigrahi et al., 2017).

Upaya untuk menghindari risiko potensial yang terkait dengan residu obat pada makanan, kontrol kehadiran antibiotik dalam susu dan produk lain yang berasal dari hewan telah diatur secara hukum di beberapa negara. Pusat Administrasi Obat dan Makanan Amerika Serikat untuk Medis Veteriner (Food and Drug Administration Center for Veterinary Medicine, United States), telah menetapkan toleransi jumlah keberadaan residu antibiotik dan tingkat aman residu antibiotik dalam susu untuk melindungi konsumen (Quintanilla et al., 2019).

Indonesia menetapkan batasan minimum residu antibiotika sesuai dengan yang telah tercantum di dalam SNI-01-6366-2000. Batasan toleransi yang di izinkan terdapat dalam produk susu menurut SNI untuk antibiotik jenis oksitetrasiklin yaitu $0.05 \mathrm{mg} / \mathrm{kg}$.

Oksitetrasiklin merupakan antibiotik golongan tetrasiklin dengan aktivitas spektrum luas, secara ekstensif digunakan dengan tujuan pengobatan pada manusia dan secara intensif digunakan dalam mendukung sistem peternakan dan budidaya perairan. Terapi yang efektif sesuai standar yang di tetapkan oleh NCCLS (National Comittee for Clinical Laboratory Standarts) yaitu apabila penggunaan oksitetrasiklin dengan konsentrasi pada plasma diatas $4 \mu \mathrm{g} / \mathrm{ml}$, untuk mencapai target bakteri tidak resisten pada oksitetrasiklin. Pada terapi dengan dosis 20 $\mathrm{mg} / \mathrm{kg}$, konsentrasi oksitetrasiklin maksimum pada serum dapat mencapai $4.10 \mu \mathrm{g} / \mathrm{ml}$ untuk sapi, sedangkan untuk hewan lainnya puncak konsentrasi dan waktu paruh dari oksitetrasiklin di darah dapat dicapai 4-16 jam dan 21-63 jam setelah pemberian. Konsentrasi oksitetrasiklin pada plasma dapat terjaga pada ataupun diatas $0.5 \mu \mathrm{g} / \mathrm{ml}$ (konsentrasi hambatan minimum) untuk kurang lebih selama 6 hari (Chi et al., 2014).

Residu antibiotik masuk kedalam tubuh melalui sebuah mekanisme yang beruhubungan dengan aktivitas absorbsi suatu antibiotika di dalam tubuh. Antibiotik masuk ke dalam tubuh 
Tabel 1. Hasil pengamatan pengujian residu antibiotik oksitetrasiklin terhadap 26 sampel

\begin{tabular}{|c|c|c|}
\hline \multirow{2}{*}{ Nomor Sampel } & \multicolumn{2}{|r|}{ Pengamatan } \\
\hline & Zona hambat (mm) & Keterangan \\
\hline 1 & - & Negatif \\
\hline 2 & - & Negatif \\
\hline 3 & - & Negatif \\
\hline 4 & - & Negatif \\
\hline 5 & - & Negatif \\
\hline 6 & - & Negatif \\
\hline 7 & - & Negatif \\
\hline 8 & - & Negatif \\
\hline 9 & - & Negatif \\
\hline 10 & - & Negatif \\
\hline 11 & - & Negatif \\
\hline 12 & - & Negatif \\
\hline 13 & - & Negatif \\
\hline 14 & - & Negatif \\
\hline 15 & - & Negatif \\
\hline 16 & - & Negatif \\
\hline 17 & - & Negatif \\
\hline 18 & - & Negatif \\
\hline 19 & - & Negatif \\
\hline 20 & - & Negatif \\
\hline 21 & - & Negatif \\
\hline 22 & - & Negatif \\
\hline 23 & - & Negatif \\
\hline 24 & - & Negatif \\
\hline 25 & - & Negatif \\
\hline 26 & - & Negatif \\
\hline \multirow[t]{2}{*}{ Kontrol + } & $18 \mathrm{~mm}$ & Konsentrasi oksitetrasiklin $1 \mu \mathrm{g} / \mathrm{ml}$ \\
\hline & Jumlah sampel positif & $0 / 26$ \\
\hline
\end{tabular}
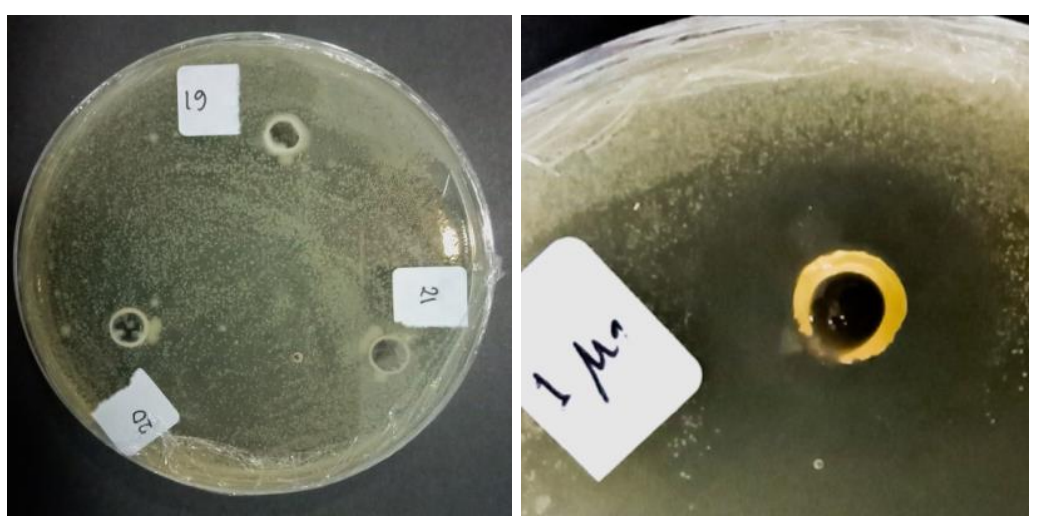

Gambar 1. Sampel susu setelah inkubasi dan kontrol positif oksitetrasiklin

hewan umumnya karena pernah dilakukan metabolisme di dalam tubuh melalui ginjal tindakan pengobatan terhadap hewan tersebut, untuk mengatasi suatu penyakit infeksi tertentu. Antibiotik yang masuk ke dalam tubuh akan di maupun hepar. Antibiotik kemudian di distribusikan ke seluruh tubuh melalui sirkulasi darah dalam tubuh. Antibiotik oksitetrasiklin 
merupakan antibiotik yang dapat dengan mudah di distribusikan ke hampir seluruh organ dan jaringan. Antibiotik golongan tetrasiklin termasuk oksitetrasiklin dapat didistribusikan melalui transplasenta, masuk pada sistem sirkulasi fetus dan dapat didistribusikan melalui susu. Konsentrasi antibiotik pada susu menunjukan kadar yang lebih tinggi dibanding pada serum ketika kelenjar mamae atau ambing sedang mengalami inflamasi atau keradangan (Plumb, 2009; Pradika et al., 2019).

Residu antibiotik yang masuk kedalam tubuh akan berinteraksi dengan mikrobiom yang memiliki bermacam-macam mikroorganisme yang berhabitat di dalam tubuh manusia. Asupan harian residu antibiotika yang berasal dari lingkungan sebagian besar akan masuk ke dalam saluran gastrointestinal, dimana diperkirakan 800-100 bakteri yang berbeda dan lebih dari 7000 strain yang berbeda hidup di dalamnya (Jernberg et al., 2010). 95\% dari jumlah mikroba tersebut merupakan bakteri yang menguntungkan, dan beberapa lainnya adalah bakteri berbahaya dan patogen oportunistik. Terdapat keseimbangan mikro-ekologi antara bakteri tersebut dan tubuh manusia sepanjang waktu. Penelitian observasi, klinik dan epidemiologi menemukan adanya peningkatan paparan antibiotik berkaitan kuat dengan perubahan komposisi mikrobiom di dalam intestinal (Fikri et al., 2018).

Hal ini dapat meningkatkan bahaya resistensi bakteri, yang dapat terjadi pada intestinal manusia dalam jangka waktu yang panjang. Terjadinya ketidakseimbangan mikrobiota, dapat mengarah pada terjadinya proliferasi dari bakteri berbahaya dan patogen oportunistik, lebih jauh lagi dapat menyebabkan berbagai macam penyakit seperti pseudomembranous colitis, kelainan intestin dan kanker colorektal. Kejadian yang lebih buruk yaitu apabila bakteri dalam usus telah resisten, kemudian berkembang biak dengna jumlah yang cukup banyak, maka penyakit - penyakit yang di sebabkan karena bakteri tersebut akan dapat menyebabkan kematian karena tidak dapat diobati (Ben, 2018).
Bahaya residu antibiotika ini tentu dapat dihindari dan dikendalikan, dengan cara memperhatikan faktor-faktor penyebab terjadinya (Fikri et al., 2018). Sebagai pengendalian jangka panjang untuk mencegah terjadinya residu antibiotik dalam pangan asal hewan, Nisha (2008) menyebutkan beberapa upaya yang dapat dilakukan yaitu, memunculkan kesadaran individual maupun kelompok masyarakat mengenai permasalahan ini melalui edukasi oleh petugas veteriner, organisasi, literatur, dan instansi pemerintahan, melakukan uji cepat (rapid screening methode) untuk menganalisa adanya residu antibiotik dan penentuan kelayakan makanan berdasarkan batas maksimum residu yang telah di tentukan, pemrosesan pada susu dapat membantu menginaktivasi antibiotik. Seperti proses pendinginan maupun pasteurisasi, untuk menginaktivasi antibiotik, dapat menggunakan arang atau karbon aktif, resin dan iradiasi sinar ultraviolet, mencegah adanya penggunaan antibiotik secara tidak rasional dalam praktik veteriner di lapangan, menciptakan sebuah uji yang sederhana dan ekonomis yang dapat dilakukan di lapangan untuk mengidentifikasi adanya residu obat pada produk pangan asal hewan, pengawasan secara luas dan survey berkala residu mikrobial pada jaringan hewan yang dapat atau biasa di konsumsi dan susu.

\section{KESIMPULAN}

Pengujian residu oksitetrasiklin dengan metode screening test menunjukkan tidak ditemukan pada susu kambing PE yang berasal dari kelurahan Kalipuro, Banyuwangi. Sebanyak $100 \%$ dari 26 sampel yang di periksa menunjukkan hasil yang negatif terhadap adanya residu antibiotik oksitetrasiklin.

\section{UCAPAN TERIMA KASIH}

Penulis mengucapkan terimakasih kepada Universitas Airlangga PSDKU Banyuwangi atas dukungan fasilitas sehingga penelitian ini dapat diselesaikan. Peneliti juga mengucapkan terimakasih kepada seluruh pihak yang telah 
bekerjasama sehingga seluruh kegiatan dapat dilaksanakan dengan baik.

\section{DAFTAR PUSTAKA}

Bahri, S., Masbulan, E., Kusumaningsih, A. 2005. Proses praproduksi sebagai faktor penting dalam menghasilkan produk ternak yang aman untuk manusia. J. Litbang. Pertanian, 24(1), 27-35.

Ben, Y., Fu, C., Hu, M., Liu, L., Wong, M. H., Zheng, C. 2018. Human health risk assessment of antibiotic resistance associated with antibiotic residues in the environment: A review. Environmental research.

Budiarsaha, I., Sutama, I.K. 2014. Efisiensi Produksi Susu Kambing Peranakan Etawah. JITV., 19(3).

Chi, Z., Liu, R., You, H., Ma, S., Cui, H., Zhang, Q. 2014. Probing the in vitro cytotoxicity of the veterinary drug oxytetracycline. PloS one, 9(7), e102334.

Detha, A. 2014. Pengujian Residu Antibiotik Pada Susu. J. Kajian Vet., 2(2), 203-208.

Dewi, A.A.S., Widdhiasmoro, N.P., Nurlatifah, I., Riti, N., Purnawati, D. 2014. Residu Antibiotika pada Pangan Asal Hewan, Dampak dan Upaya Penanggulangannya. BBVet Denpasar.

Fikri, F., Purnama, M.T.E., Saputro, A.L., Hamid, I.S. 2018. Identifikasi Escherichia coli dan Salmonella spp pada Karkas Sapi di Rumah Potong Hewan di Banyuwangi dan Resistensi Terhadap Antibiotika. J. Sain Vet., 36(1), 123-128.

Ferichani, M., Darsono, D., Supanggyo, S. 2017. Inovasi Produk Es Krim Susu Kambing Etawah-Ubi Ungu. Caraka Tani: J. Sustainable Agric., 27(1), 35-43.
Jernberg, C., Löfmark, S., Edlund, C., Jansson, J. K. 2010. Long-term impacts of antibiotic exposure on the human intestinal microbiota. Microbiol., 156(11), 3216-3223.

Meutia, N. 2016. Residu Antibiotika dalam Air Susu Segar Yang Berasal dari Peternakan di Wilayah Aceh Besar. J. Ilmu Ternak, 16(1).

Ningrum, S.G. 2011. Pengujian Residu Antibiotika dalam Susu Segar dari Beberapa Peternakan Sapi Perah di Provinsi Jawa Barat Menggunakan Metode Bioassay.

Nisha, A.R. 2008. Antibiotic residues-a global health hazard. Vet. World, 1(12), 375.

Panigrahi, S., Sheoran, M.S., Ganguly, S. 2017. Antibiotic residues in milk-a serious public health hazard. J. Environ. Life Sci., 2(4), 99102.

Pikkemaat, M.G. 2009. Microbial screening methods for detection of antibiotic residues in slaughter animals. Anal. Bioanal. Chem., 395(4), 893-905.

Plumb, D.C. 2009. Veterinary Drug Handbook $7^{\text {th }}$ Edition. Pharmavet. Stockholm, Wisconsin.

Pradika, A.Y., Chusniati, S., Purnama, M.T.E., Effendi, M.H., Yudhana, A., Wibawati, P. A. 2019. Uji Total Escherichia coli pada Susu Sapi Segar di Koperasi Peternak Sapi Perah (KPSP) Karyo Ngremboko Kecamatan Purwoharjo Kabupaten Banyuwangi. J. Med. Vet., 2(1), 1-6.

Quintanilla, P., Beltrán, M.C., Molina, A., Escriche, I., Molina, M.P. 2019. Characteristics of ripened Tronchón cheese from raw goat milk containing legally admissible amounts of antibiotics. J. Dairy Sci., 102(4), 2941-2953.

Standar Nasional Indonesia. 2000. SNI Nomor 01-6366-2000 Tentang Batas Maksimum 
Cemaran Mikroba dan Batas Maksimum Residu dalam Bahan Makanan Asal Hewan. Jakarta: Badan Standardisasi Nasional.

Standar Nasional Indonesia. 2008. SNI Nomor 7442: 1995 Tentang Metode Uji Tapis (Screening Test) Residu Antibiotika pada
Daging, Telur dan Susu Secara Bioassay. Jakarta: Badan Standardisasi Nasional.

Suwito, W., Nugroho, W.S., Sumiarto, B., Wahyuni, A.E.T.H. 2014. Faktor-Faktor Risiko Mastitis Subklinis pada Kambing Peranakan Etawah di Kabupaten Sleman, Yogyakarta. J. Vet., 15(1), 130-138. 